\title{
The influence of thermal treatment on the electrochemical properties of carbon-Ni-Pd composites
}

\author{
Jan M. Skowroński • Małgorzata Osińska
}

Received: 10 October 2013/Accepted: 19 March 2014/Published online: 30 March 2014

(C) The Author(s) 2014. This article is published with open access at Springerlink.com

\begin{abstract}
Resorcinol-formaldehyde (RF) hydrogel and RF-nickel-palladium (RF-Ni-Pd) hydrogel were synthesized by sol-gel polycondensation followed by ambient drying. Carbon gel and carbon-nickel-palladium doped gels were prepared by carbonizing the RF and RF-Ni-Pd gels at $900{ }^{\circ} \mathrm{C}$ under a nitrogen atmosphere. The goal of this study was to determine the effect of oxidative thermal treatment on the electrochemical activity of nickel-palladium doped carbon gels (C-Ni-Pd). The scanning electron microscopy analysis, adsorption and X-ray diffraction measurements showed that the admixture of $\mathrm{Ni}$ and $\mathrm{Pd}$ to carbon matrix resulted in the modification of morphological, porous and crystalline features. It has been demonstrated that composite $\mathrm{C}-\mathrm{Ni}-\mathrm{Pd}$ composed of sphere-like granules incrusted with well-crystalline nickel and palladium particles exhibits electrochemical activity in $6 \mathrm{M}$ $\mathrm{KOH}$ aqueous solution. Thermal treatment of the composite carried out in air at $450{ }^{\circ} \mathrm{C}$ brought about the improvement of electrochemical activity in the potential range of the hydrogen sorption/desorption reaction.
\end{abstract}

Keywords Carbon gel · Carbon-nickel-palladium composite · TGA-DSC · SEM-EDS · Nitrogen adsorption · XRD $\cdot$ Cyclic voltammetry $\cdot$ Electrochemical hydrogen storage

J. M. Skowroński $(\bowtie) \cdot$ M. Osińska

Faculty of Chemical Technology, Institute of Chemistry and

Technical Electrochemistry, Poznań University of Technology,

ul. Piotrowo 3, 60-965 Poznan, Poland

e-mail: jan.skowronski@put.poznan.pl

\section{Introduction}

During recent years, the amount of studies on carbon materials as a hydrogen storage system has increased due to the light weight and excellent kinetics of these materials [1-3].

The hydrogen storage in a commercial activated carbon, impregnated with nickel $[4,5]$ or carbon nanofibers of a herringbone type structure, obtained on Pd catalyst [6] have been studied. In comparison with traditional activated carbons, carbon gels present a series of advantages for the preparation of metal doped materials [7]. Resorcinolformaldehyde (RF) organic aerogels have been synthesized by Penkala [8] through polycondensation of resorcinol (R) with formaldehyde (F), and sodium carbonate (C) added as a catalyst (Fig. 1). Carbon gels are formed during the pyrolysis of RF aerogels. The structure and properties of carbon gels depend on the polymerization conditions [9-12] and the ratio of the substrates R/C [13, 14].

Metal-doped carbon materials are attractive for several applications, for example in electrochemistry [15-19] or catalysis [20-22]. To expand their potential applications, recent studies have focused on the modification of carbon gels through the use of doped molecules. One area of significant interest is incorporation of metal species into the carbon framework in order to modify the structure, conductivity and electrochemical activity. There are the three main methods for incorporation of metal into the carbon matrix. The first one consists in the introduction of dissolved precursor of metal to the initial RF mixture [19, 23, 24]. The second method uses parent derivatives of resorcinol containing ion-exchange moieties that could be polymerized using sol-gel techniques [25, 26]. As a result, each repeated unit of organic polymer becomes a binding site for metal ions, ensuring an uniform dispersion of the 
Fig. 1 Schematic diagram of the reaction of resorcinol with formaldehyde

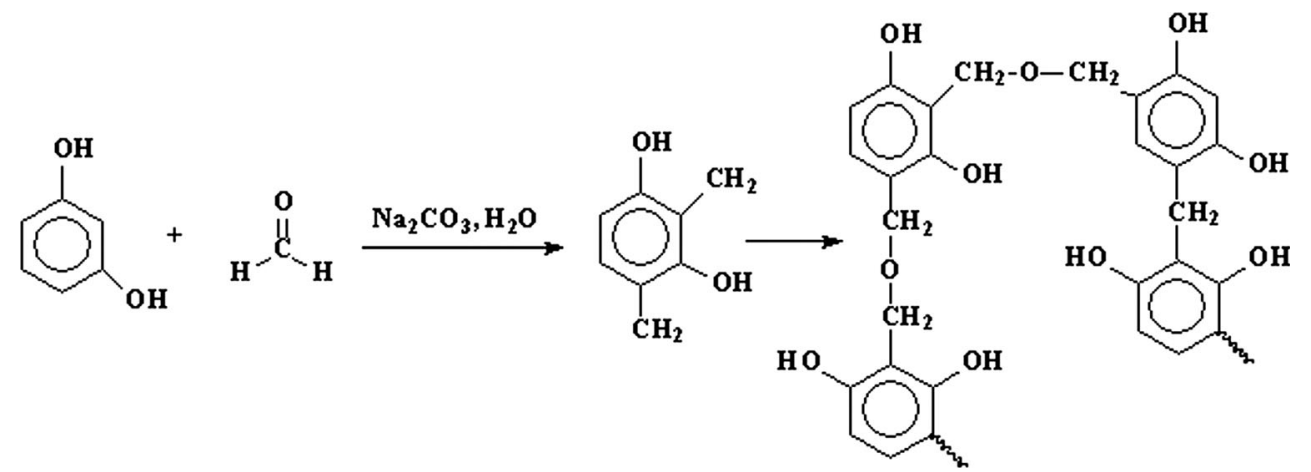

admixture. For example carbon aerogel doped with copper were prepared through sol-gel polymerization of formaldehyde with the potassium salt of 2,4-dihydroxybenzoic acid (2,4-DHBA) followed by an ion exchange with $\mathrm{Cu}\left(\mathrm{NO}_{3}\right)_{2}$ [24]. A suspension of 2,4-DHBA and formaldehyde was treated with $\mathrm{K}_{2} \mathrm{CO}_{3}$. The synthesized $\mathrm{K}^{+}$-loaded wet gels were immersed in aqueous solution of $\mathrm{Cu}\left(\mathrm{NO}_{3}\right)_{2}$, then washed with acetone, dried and carbonized. The third method involves the deposition of metallic precursor on the organic or carbon gel. For this purpose carbon aerogel powder was added into an ethanol solution of nickel(II) chloride. After stirring a solid recovered by filtration was washed, dried and calcined to obtain Nidoped carbon aerogel [27].

Different metal-doped carbon gels have already been prepared and characterized, including $\mathrm{Ce}$ and $\mathrm{Zr}$-containing carbon gels [27], $\mathrm{Cu}-[17,29,30], \mathrm{Ni}-[10,19,29-32], \mathrm{Ag}-$ [33], Pd- [3, 22-26], Co- [16, 23], Mn- [16], Ti- [16], Fe$[3,23,28]$ or Pt- $[22,26]$ doped carbon gels.

Recent studies have shown that doped metal ions rejected outside the organic phase are reduced by formaldehyde and then precipitated locally to form large crystallites located at the surface of the polymer nodules, i.e. in the meso- or macropores [34-36]. The metal particles obtained by impregnation are available to reactants but they are too large for most applications (such as catalysis and electrochemistry). Fu et al. [36] noted that for Co- and $\mathrm{Ni}$-doped aerogels, the metal nanoparticles become encased in graphitic carbon during the carbonization process and, therefore, are unable to function as catalysts for carbon nanotubes. In our previous papers, the synthesis and characterization of nickel-doped xerogels (gels dried in an inert atmosphere are called xerogels) with highly dispersed metal nanoparticles have been reported [19, 31].

The main objective of the present paper is to study the possibility of preparing transition metal-containing RF gels and their derivatives. In the present work we deal with xerogels prepared using $\mathrm{Pd}$ and $\mathrm{Ni}$ simultaneously. $\mathrm{RF}$ aerogels were obtained according the Penkala method but the basic catalyst $\left(\mathrm{Na}_{2} \mathrm{CO}_{3}\right)$ was substituted for acetate of $\mathrm{Pd}$ and Ni. The goal of this study was to determine the influence of oxidative thermal treatment of nickel-palladium doped carbon gels on their porous and crystalline structure and, in consequence, on the electrochemical activity in terms of the reaction of hydrogen storage.

\section{Experimental}

2.1 Preparation of carbon gel and carbon-nickelpalladium composites

RF hydrogels were synthesized by the polycondensation of resorcinol $(\mathrm{R})$ with formaldehyde $(\mathrm{F})$, and sodium carbonate (C) as a catalyst. Molar ratios R/F and R/C were 0.5 and 1,000 , respectively. Resorcinol was mixed with the catalyst and deionized water to dissolve. After the dissolution formaldehyde was added and stirred for $24 \mathrm{~h}$. The mass percentage of the reactants in water solution was set at $40 \%$.

In order to obtain carbon-nickel-palladium composites (C-Ni-Pd) $\mathrm{Na}_{2} \mathrm{CO}_{3}$ catalyst was replaced with two metal precursors: nickel acetate $\left(\mathrm{C}_{4} \mathrm{H}_{6} \mathrm{NiO}_{4} \cdot 4 \mathrm{H}_{2} \mathrm{O}\right)$ and palladium acetate $\left(\mathrm{C}_{4} \mathrm{H}_{6} \mathrm{O}_{4} \mathrm{Pd}\right)$. The mass of nickel and palladium salts in the solution were adjusted so as to the theoretical metal mass in carbon formed after RF carbonization (carbonization conditions hereafter) was $5 \mathrm{wt} \%$ for each metal. The mass percentage of the reactants in water solution was set at $40 \%$.

These solutions were poured into polypropylene vessels that were then sealed and allowed to cure at $50{ }^{\circ} \mathrm{C}$ for $96 \mathrm{~h}$ and successively at $70{ }^{\circ} \mathrm{C}$ for $24 \mathrm{~h}$. After gelation, the RF and $\mathrm{RF}-\mathrm{Ni}-\mathrm{Pd}$ gels were removed from the drying stove and cooled at room temperature. The obtained hydrogel without nickel and palladium changed its color from colorless to brick-red, whereas $\mathrm{Ni}^{2+}$ and $\mathrm{Pd}^{2+}$-loaded organic gels were dark red.

All the samples underwent the operation of water removal through the exchange with acetone. Each sample 
of hydrogel was placed into a distillation flask and acetone was added. The distillation flask was closed by a reflux condenser and thermometer. The acetone was heated up to $56{ }^{\circ} \mathrm{C}$ to accelerate the diffusion of water from the wet RF and $\mathrm{RF} / \mathrm{Ni} / \mathrm{Pd}$ gel. Afterwards the distillation flask was cooled to room temperature and acetone was decanted. The exchange process was repeated three times using fresh acetone to remove residual water from the pores of wet gels. After cooling the gels were filtered off by decantation and finally with the use of filter paper. Ambient drying was preliminary performed at room temperature for $72 \mathrm{~h}$ and further drying was continued at $50{ }^{\circ} \mathrm{C}$ for the next $24 \mathrm{~h}$.

Subsequently the dried samples of gels were carbonized in a tube furnace under nitrogen flow at $900{ }^{\circ} \mathrm{C}$ for $3 \mathrm{~h}$ using a heating rate of $5^{\circ} \mathrm{C} / \mathrm{min}$, then the heating was turned off and the tube furnace was cooled to $50{ }^{\circ} \mathrm{C}$ for $20 \mathrm{~h}$.

The obtained products were the carbon gel without nickel and palladium (CG) and the carbon gel doped with $5 \mathrm{wt} \%$ metallic nickel and $5 \mathrm{wt} \%$ of metallic palladium (C-Ni-Pd).

After carbonization all the gels were powdered in a high-energy ball mill (Pulverisette 6, Fritsch) in an argon atmosphere. $\mathrm{CG}$ and $\mathrm{C}-\mathrm{Ni}-\mathrm{Pd}$ were milled twice at $350 \mathrm{rpm}$ for $15 \mathrm{~min}$, using a $10 \mathrm{~min}$ interruption between each milling. The mass ratio of stainless steel balls to milled material was $55: 1$. According to the results of the thermogravimetric analysis and differential scanning calorimetry (TGA-DSC) (see below in section "Thermogravimetric and differential scanning calorimetry analyses") some part of C-Ni-Pd was subjected to thermal activation in air at $450{ }^{\circ} \mathrm{C}$. For this purpose the sample was placed in a furnace, heated up to $450{ }^{\circ} \mathrm{C}$ at a heating rate of $5^{\circ} \mathrm{C} \min ^{-1}$ and then left there at $450{ }^{\circ} \mathrm{C}$ for $30 \mathrm{~min}$. The product of such a treatment was denoted as $\mathrm{C}-\mathrm{Ni}-\mathrm{Pd} / \mathrm{T}$.

\subsection{Sample characterization}

TGA and DSC measurements were carried out for CG and C-Ni-Pd using a Setsys 1200 equipment (Setaram). Samples of about $20 \mathrm{mg}$ were heated up to $1,000{ }^{\circ} \mathrm{C}$ with a heating rate of $5^{\circ} \mathrm{C} \mathrm{min}^{-1}$ in order to determine the thermal characteristics of $\mathrm{CG}$ and $\mathrm{C}-\mathrm{Ni}-\mathrm{Pd}$ in air.

A scanning electron microscopy (SEM) (Hitachi S-3400 N) coupled with the energy dispersive spectrometer (EDS) (Thermo Electron Corp., model No. 4481B-1UESSN with the NSS Spectral Imaging System software) was used for observing the morphology and distribution of the active particles on the sample surface as well as determining semi-quantitatively their chemical composition.

The BET specific surface areas $\left(S_{\mathrm{BET}}\right)$ of samples were determined from the isotherms measured by $\mathrm{N}_{2}$ adsorption at $-195.5^{\circ} \mathrm{C}$ using a relative pressure ranging from 0.06 to
0.30 (ASAP2020 V3.01 H-Micromeritics porosimeter). The cumulative pore volume $\left(V_{\mathrm{CUM}}\right)$ between 1.7 and $300 \mathrm{~nm}$ and mesopore size distributions were determined from the desorption branch of the $\mathrm{N}_{2}$ isotherm using the Barret-Joyner-Halenda (BJH) method.

The X-ray analyses were performed with a diffractometer BRUKER D8 Advance, equipped with a computer control set. The measurements were done using a $\mathrm{CuK} \alpha$ radiation (wavelength of $0.1542 \mathrm{~nm}$ ) with nickel filtering.

\subsection{Preparation of electrodes and evaluation of electrochemical properties}

The working electrode was made by the insertion of $20 \mathrm{mg}$ of powdered electrode material placed on a gold spiral, playing the role of current collector, mounted on the bottom of the vessel of measuring cell. Before the measurement electrode was immersed in $6 \mathrm{M} \mathrm{KOH}$ solution for $24 \mathrm{~h}$ to ensure the diffusion of aqueous electrolyte solution into the pores of carbon material.

Cyclic voltammetry (CV) was used to determine the electrochemical properties of the carbon gel and carbonmetals composite electrodes. CV measurements were carried out in a three-electrode cell filled with $6 \mathrm{M} \mathrm{KOH}$ solution. Powdery gels placed on a current collector served as a working electrode. A $\mathrm{Hg} / \mathrm{HgO} / 6 \mathrm{M} \mathrm{KOH}$ system $(-0.098 \mathrm{~V}$ vs. normal hydrogen electrode) and a platinum spiral were used as the reference and counter electrode, respectively. All potentials in the paper are related to a $\mathrm{Hg} / \mathrm{HgO} / 6 \mathrm{M} \mathrm{KOH}$ reference electrode. The $\mathrm{CV}$ measurements were carried out in the potential range from -1.2 to $0.0 \mathrm{~V}$, starting from the rest potential of the electrode with a scan rate of $1 \mathrm{mV} / \mathrm{s}$. The potential was changed in the negative direction (cathodic polarization) to reach $-1.2 \mathrm{~V}$ and after the reversal of polarization direction the potential was increased until the limit potential $0.0 \mathrm{~V}$ was reached. At this moment the polarization was reversed again. During the third cycle after reaching the potential $-1.2 \mathrm{~V}$ the measurement was stopped for $30 \mathrm{~min}$ for the saturation of the electrode with hydrogen and the next cycle was continued in the positive direction. After the first 10 cycles carried out as described above, the electrode was left in $\mathrm{KOH}$ solution for $15 \mathrm{~h}$ at an open circuit and then the second series of 10 cycles was made but without the potential stopping. The $\mathrm{CV}$ measurements were carried out like those of the first 10 cycles, i.e. they were started at the rest potential of the electrode and then the potential scanning was carried out towards negative direction down to the limit potential of $-1.2 \mathrm{~V}$. Also, the potential range and scan rate remained unchanged. All measurements were carried out at room temperature using $\mu$ AUTOLAB (type II) potentiostat-galvanostat. 


\section{Results and discussion}

\subsection{Thermogravimetric and differential scanning calorimetry analyses}

The thermal stability of $\mathrm{C}-\mathrm{Ni}-\mathrm{Pd}$ against air was examined using thermal analysis. Thermal scanning was done at the temperature range from 20 to $1,000{ }^{\circ} \mathrm{C}$. The TG curve of carbon-metals gel (Fig. 2) demonstrates no significant weight loss at temperatures below $500{ }^{\circ} \mathrm{C}$ but on increasing the temperature the sample weight decreases abruptly to be completely burned-out at around $700{ }^{\circ} \mathrm{C}$. A double peak with the maxima at 550 and $700{ }^{\circ} \mathrm{C}$ is recorded on the DSC curve. The first exothermal peak is associated with the oxidation reaction of carbon with air resulting in burning out the carbon skeleton. The second one being accompanied by a small increase of mass on the TG curve can be ascribed to a violent oxidation of highly active metal particles exposed to air. The results of the TG-DSC measurements yielded information that the process of oxidative

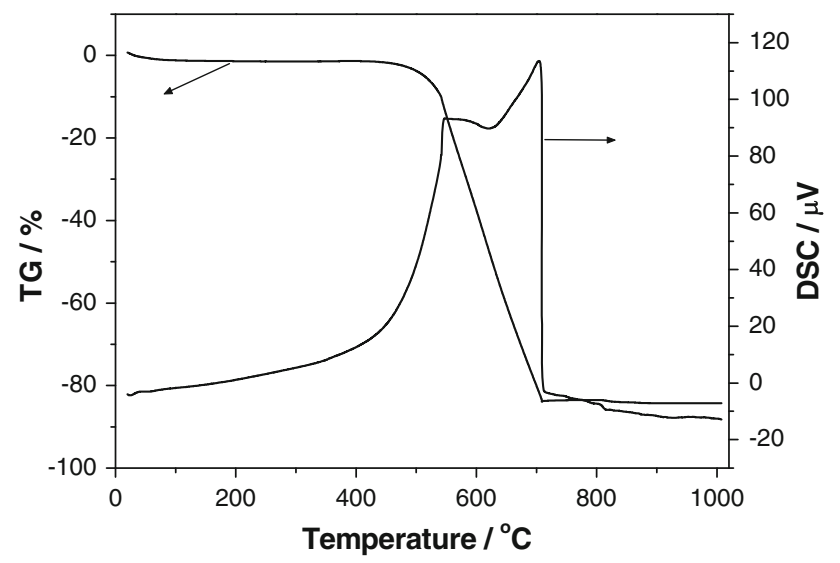

Fig. 2 TG and DSC curves recorded in air atmosphere (heating rate: $5{ }^{\circ} \mathrm{C} / \mathrm{min}$ ) for composite $\mathrm{C}-\mathrm{Ni}-\mathrm{Pd}$ thermal treatment of samples should be performed at temperatures below $500{ }^{\circ} \mathrm{C}$ to prevent thermal decomposition of xerogel.

\subsection{Morphological properties}

The SEM images of CG and C-Ni-Pd shown in Figs. 3 and 4 allow us to observe the changes in morphology by the addition of the nickel and palladium salts to reaction mixture. As seen from Fig. 3a, b, carbon material of sample CG consists of particles different in shape with the majority in dimensions from 5 to $10 \mu \mathrm{m}$ in diameter.

In the case of our gels we observed that multi-shape particles of sharp edges (Fig. 3) changed into sphere-like beads when nickel and palladium were added (Fig. 4). Spherical particles are visible for sample C-Ni-Pd (Fig. 4), whereas brickets-like particles can be observed for CG free of metal dopants (Fig. 3). Moreover, the particle dimensions of composites $\mathrm{C}-\mathrm{Ni}-\mathrm{Pd}$ and $\mathrm{C}-\mathrm{Ni}-\mathrm{Pd} / \mathrm{T}(1-5 \mu \mathrm{m}$ in diameter) are smaller than for those of xerogel CG. Light spots observed on the carbon surface in Fig. 4 correspond to metallic catalyst: nickel and palladium particles. Their size varies from 0.01 to $0.3 \mu \mathrm{m}$.

Based on the results of the EDS analysis (Table 1) one can notice the increase in oxygen content by the heat treatment in air. This fact can be attributed to both the formation of oxygen functional groups on the carbon surface and the formation of $\mathrm{Ni}-\mathrm{Pd}$ oxide on the metal surface.

The influence of nickel-palladium salts added to the RF gel and their conversion to metallic nickel and palladium due to heat treatment can be evaluated by comparing the images shown in Fig. 4 with those presented in Fig. 3. As has been reported previously [19, 32, 37], the presence of metal precursors in the RF solution changes the mechanism of the polymerization process. From the comparison of Fig. $4 a, b$ with Fig. $4 c, d$ it is seen that the process of heat treatment of $\mathrm{C}-\mathrm{Ni}-\mathrm{Pd}$ in air at $450{ }^{\circ} \mathrm{C}$ caused no changes
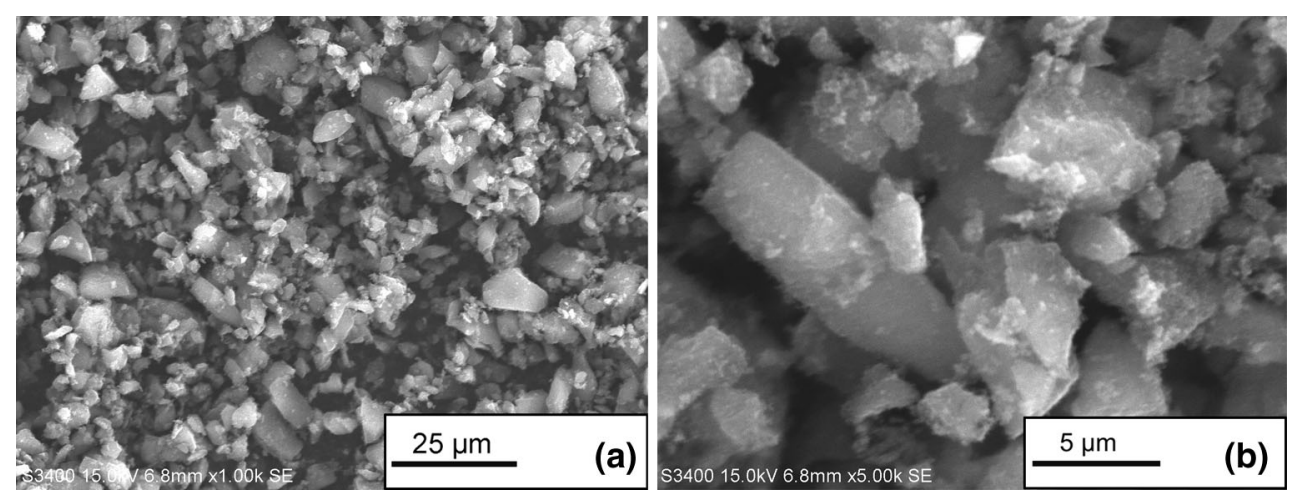

Fig. 3 SEM images for carbon gel CG 

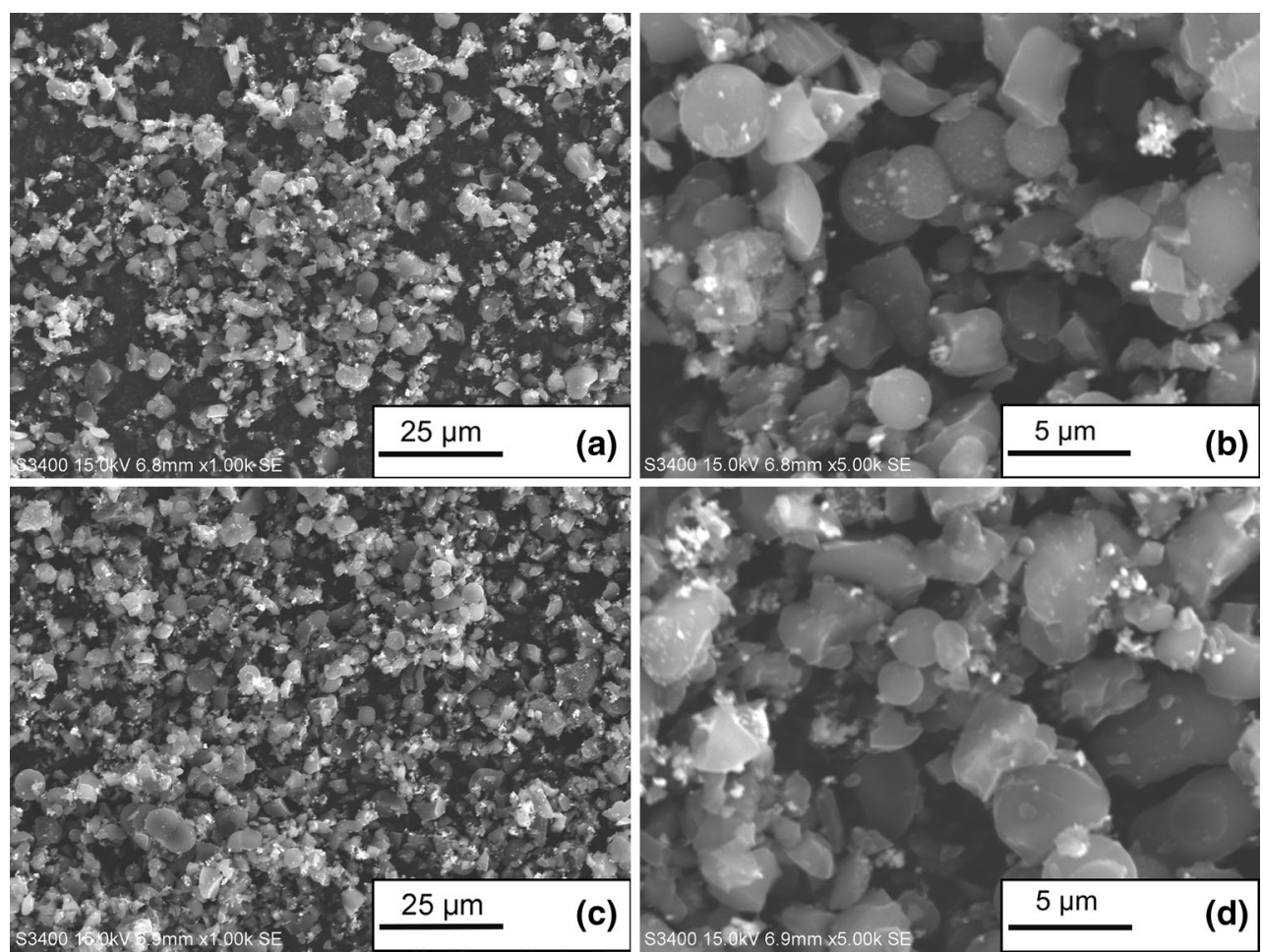

Fig. 4 SEM images for composites $\mathrm{C}-\mathrm{Ni}-\mathrm{Pd}(\mathbf{a}, \mathbf{b})$ and $\mathrm{C}-\mathrm{Ni}-\mathrm{Pd} / \mathrm{T}(\mathbf{c}, \mathbf{d})$

Table 1 Semi-quantitative EDS analysis data for composite $\mathrm{C}-\mathrm{Ni}-$ Pd before and after thermal heat treatment

\begin{tabular}{llc}
\hline Element (at.\%) & \multicolumn{2}{l}{ Composition } \\
\cline { 2 - 3 } & C-Ni-Pd & C-Ni-Pd/T \\
\hline $\mathrm{C}$ & 93.70 & 89.07 \\
$\mathrm{O}$ & 4.67 & 8.35 \\
$\mathrm{Ni}$ & 0.84 & 1.28 \\
$\mathrm{Pd}$ & 0.79 & 1.30 \\
\hline
\end{tabular}

in morphology but contributed to the modification of chemical composition of the sample surface (Table 1).

\subsection{Physical properties}

The porous structures of the obtained $\mathrm{CG}$ and $\mathrm{C}-\mathrm{Ni}-\mathrm{Pd}$ were characterized using the BET and BJH measurements (Table 2). The specific surface area for CG free of metals amounted to $618 \mathrm{~m}^{2} / \mathrm{g}$. The presence of $\mathrm{Pd}$ and $\mathrm{Ni}$ formed in the carbon matrix contributed to the decrease of the BET surface area down to $530 \mathrm{~m}^{2} / \mathrm{g}$ (composite $\mathrm{C}-\mathrm{Ni}-\mathrm{Pd}$ ). Metal particles incorporated in carbon matrix noticeably changed the porous structure of these gels (Fig. 5). As seen from Table 2, the highest average pore diameter of $d_{\mathrm{BJH}}=$ $15.25 \mathrm{~nm}$ measured for $\mathrm{CG}$ free of metals was a sixfold higher compared to that of composite $\mathrm{C}-\mathrm{Ni}-\mathrm{Pd}\left(d_{\mathrm{BJH}}=\right.$
Table 2 Porous structure data of carbon gel and nickel-palladiumdoped carbon gels

\begin{tabular}{llll}
\hline Sample & $S_{\mathrm{BET}}\left(\mathrm{m}^{2} / \mathrm{g}\right)$ & $\begin{array}{l}\text { Average pore } \\
\text { diameter } d_{\mathrm{BJH}}(\mathrm{nm})\end{array}$ & $\begin{array}{l}V_{\mathrm{CUM}} \\
\left(\mathrm{cm}^{3} / \mathrm{g}\right)\end{array}$ \\
\hline $\mathrm{CG}$ & 618 & 15.25 & 0.86 \\
$\mathrm{C}-\mathrm{Ni}-\mathrm{Pd}$ & 530 & 2.40 & 0.05 \\
$\mathrm{C}-\mathrm{Ni}-\mathrm{Pd} / \mathrm{T}$ & 602 & 2.80 & 0.07 \\
\hline
\end{tabular}

$2.40 \mathrm{~nm}$ ). On considering the structural data presented in this Table it is clear that the reactions involving the conversion of nickel and palladium acetates dissolved in aqueous RF solution to metallic Ni-Pd particles led to the decrease of average pore diameter of mesopores and, as a consequence, their cumulative volume. Because, on the other hand, the BET surface area for composites $\mathrm{C}-\mathrm{Ni}-\mathrm{Pd} / \mathrm{T}$ became about $12 \%$ higher due to thermal activation $\left(602 \mathrm{~m}^{2} / \mathrm{g}\right)$ as compared to that of composite $\mathrm{C}-\mathrm{Ni}-\mathrm{Pd}$ $\left(530 \mathrm{~m}^{2} / \mathrm{g}\right)$ one can reasonably assume that the number of pores of lower diameters, with a larger average pore diameter of $d_{\mathrm{BJH}}=2.80$, increased during this process. This conclusion is consistent with the structural data plotted in Fig. 6.

The XRD analysis of nickel and palladium free CG showed the presence of two diffraction peaks characteristic of disordered carbon (Fig. 7). The large and broad 


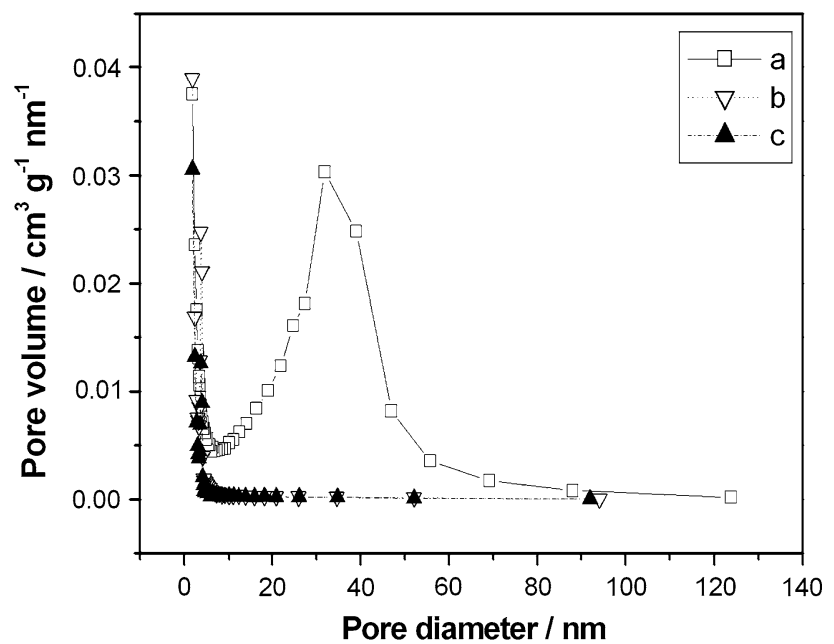

Fig. 5 Pore volume distributions calculated from nitrogen adsorption isotherms for carbon gel CG (a), composites $\mathrm{C}-\mathrm{Ni}-\mathrm{Pd}(\mathbf{b})$ and $\mathrm{C}-\mathrm{Ni}-$ $\mathrm{Pd} / \mathrm{T}(\mathbf{c})$

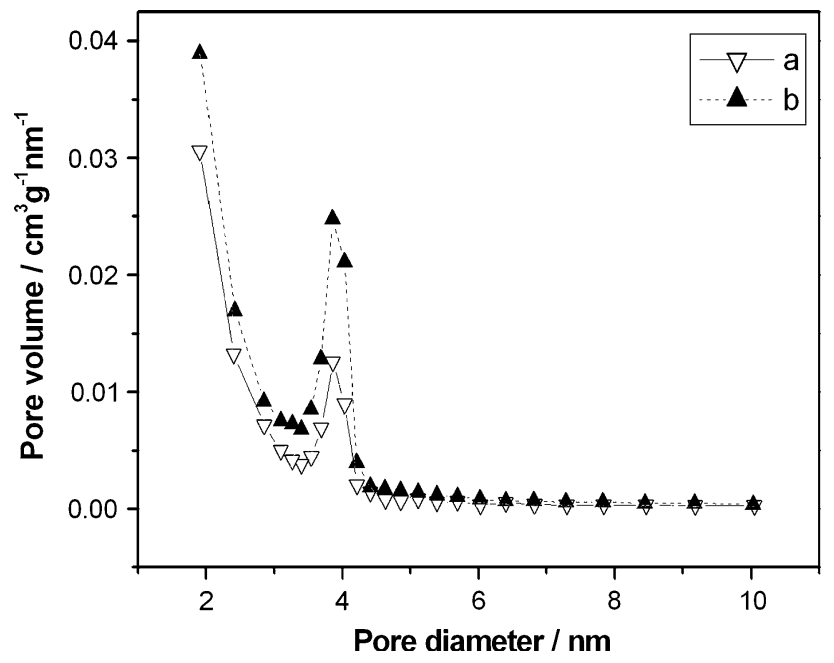

Fig. 6 Pore volume distributions calculated from nitrogen adsorption isotherms for composites $\mathrm{C}-\mathrm{Ni}-\mathrm{Pd}$ (a) and $\mathrm{C}-\mathrm{Ni}-\mathrm{Pd} / \mathrm{T}$ (b)

diffraction peaks at $2 \theta=23.6^{\circ}$ and $44.1^{\circ}$ can be attributed to the (002) and (101) graphitic nanodomains, respectively, embedded in the matrix of disordered carbon. One broad diffraction peak characteristic of turbostratic carbon at about $2 \theta=24^{\circ}$ is also presented on the XRD pattern recorded for metals-doped gels (Fig. 8). On the XRD pattern recorded for $\mathrm{C}-\mathrm{Ni}-\mathrm{Pd}$ before thermal treatment (Fig. 8a), three sharp peaks corresponding to crystalline palladium are visible at $2 \theta=41^{\circ}, 47^{\circ}$ and $69^{\circ}$. The other diffraction peaks at $2 \theta=44^{\circ}, 52^{\circ}$ are assigned to crystalline nickel. As compared with the XRD pattern for sample $\mathrm{C}-\mathrm{Ni}-\mathrm{Pd}$ before thermal treatment (Fig. 8a) the pattern recorded for $\mathrm{C}-\mathrm{Ni}-\mathrm{Pd}$ after thermal treatment in air

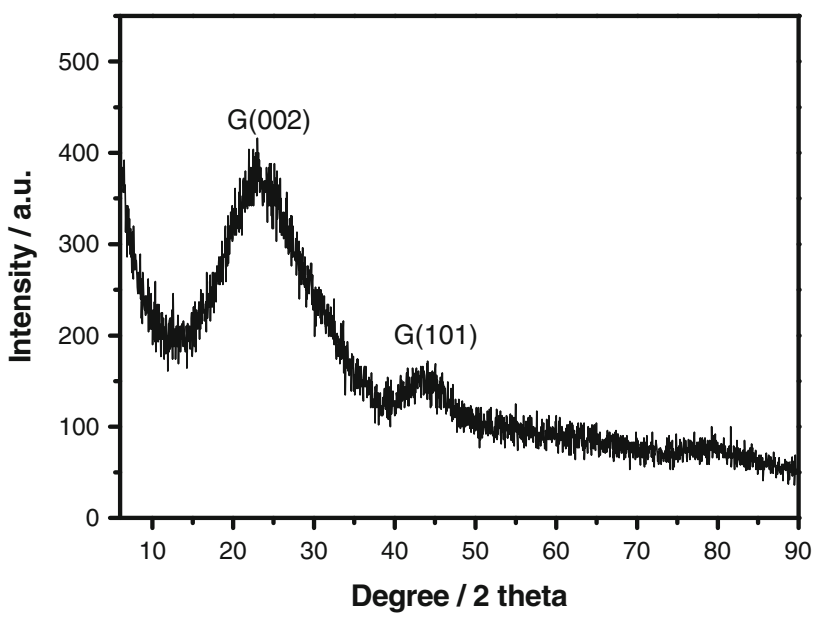

Fig. 7 XRD pattern for carbon gel CG
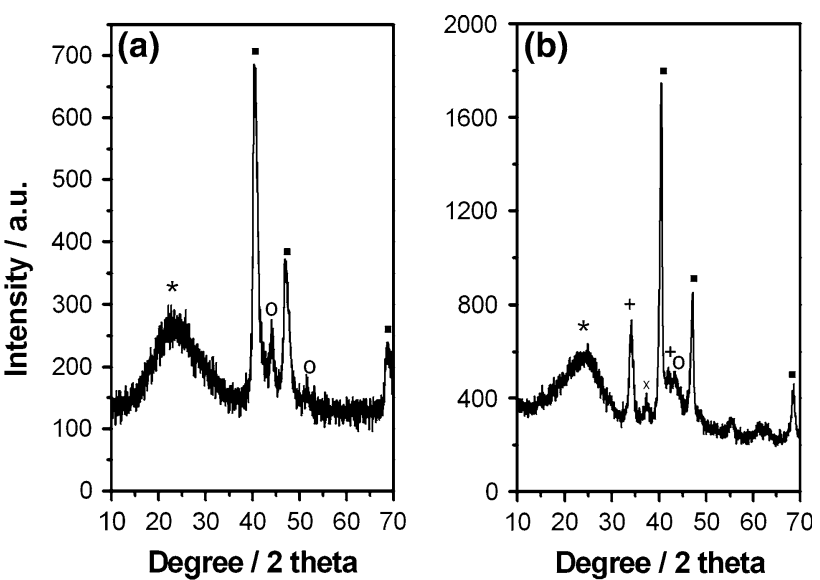

Fig. 8 XRD patterns for composites C-Ni-Pd (a) and C-Ni-Pd/T (b). Peak positions: (*) graphite, (ם) $\mathrm{Pd},(+) \mathrm{PdO},(\mathbf{o}) \mathrm{Ni},(\mathrm{x}) \mathrm{NiO}$

atmosphere at $450{ }^{\circ} \mathrm{C}$ (Fig. 8b) showed the increase in the intensity of peaks arising from crystalline palladium. The diffraction peak positioned at $52^{\circ}$, corresponding to the presence of nickel, disappeared on the XRD pattern for composite $\mathrm{C}-\mathrm{Ni}-\mathrm{Pd} / \mathrm{T}$ and three additional peaks appeared. The first peak at about $37.3^{\circ}$ proves the presence of nickel oxide, whereas the second one at $2 \theta$ about $34^{\circ}$ and $2 \theta=42^{\circ}$ corresponds to palladium oxide $[38,39]$. The formation of $\mathrm{Ni}$ and Pd oxides can be related to the effect of the reaction of metal particles located at the composite surface with air.

\subsection{Electrochemical activity}

Cyclic voltammograms obtained for $\mathrm{CG}$ and $\mathrm{C}-\mathrm{Ni}-\mathrm{Pd}$ are depicted in Figs. 9, 10 and 11, respectively. From comparison of $\mathrm{CV}$ curves presented in these figures one can see that the presence of metals affected significantly their 


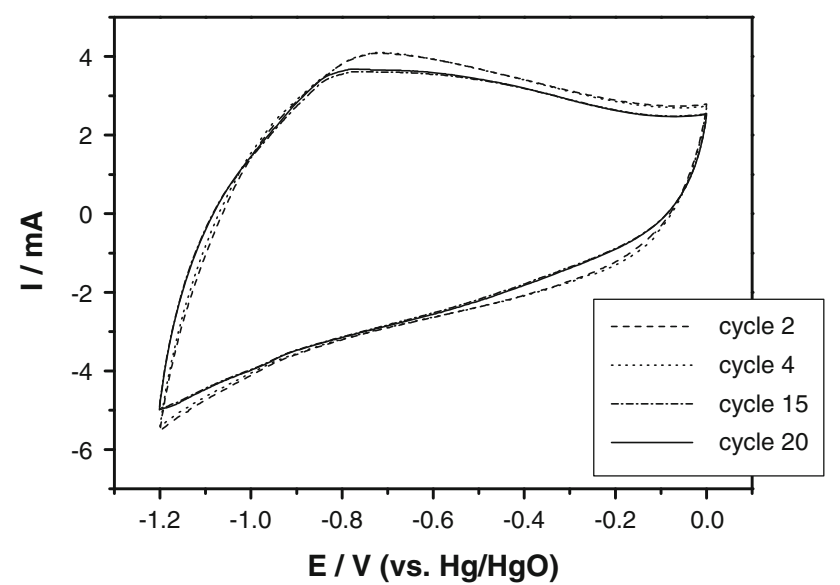

Fig. 9 Cyclic voltammograms recorded in $6 \mathrm{M} \mathrm{KOH}$ for carbon gel CG. Potential range from -1.2 to $0.0 \mathrm{~V}$. Scan rate $1 \mathrm{mV} / \mathrm{s}$

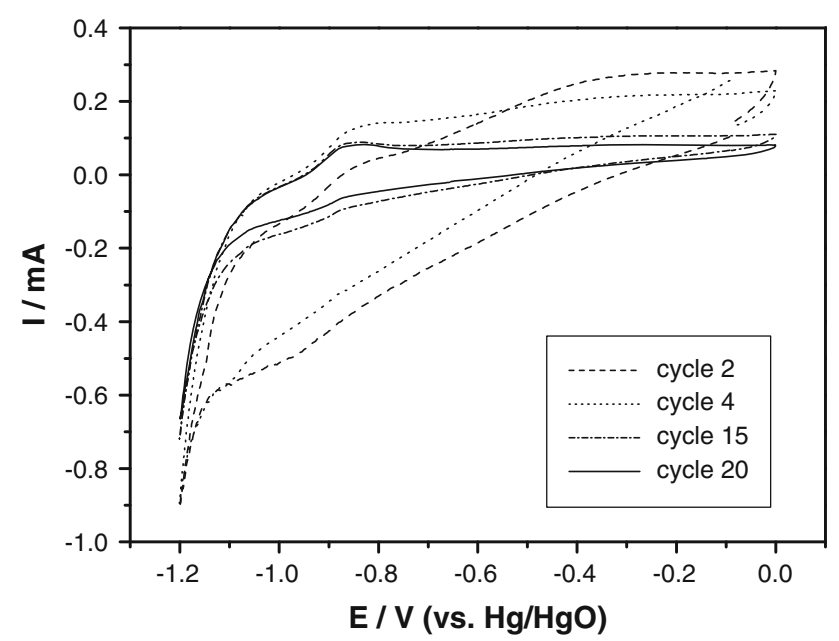

Fig. 10 Cyclic voltammograms recorded in $6 \mathrm{M} \mathrm{KOH}$ for composite $\mathrm{C}-\mathrm{Ni}$-Pd. Potential range from -1.2 to $0.0 \mathrm{~V}$. Scan rate $1 \mathrm{mV} / \mathrm{s}$

shape and current charges of the recorded reactions. As can be seen in Fig. 9, for metal free CG there are no distinct redox peaks associated with the reduction/oxidation of carbon matrix. The capacitive effects associated with the process of charging/discharging of the electrical double layer and broad humps associated with the faradaic reactions of carbon matrix are observed [19, 40].

As seen from Fig. 10, the presence of Ni-Pd dopants in the carbon matrix (composite $\mathrm{C}-\mathrm{Ni}-\mathrm{Pd}$ ) dramatically altered the character of voltammograms.

The created changes consist in both the significant decrease in the anodic and cathodic charge and the appearance of a couple of current peaks in the potentials lower than $-0.7 \mathrm{~V}$. The total BET surface area was found to decrease due to the insertion of nickel and palladium into the carbon matrix (Table 2). An additional effect of

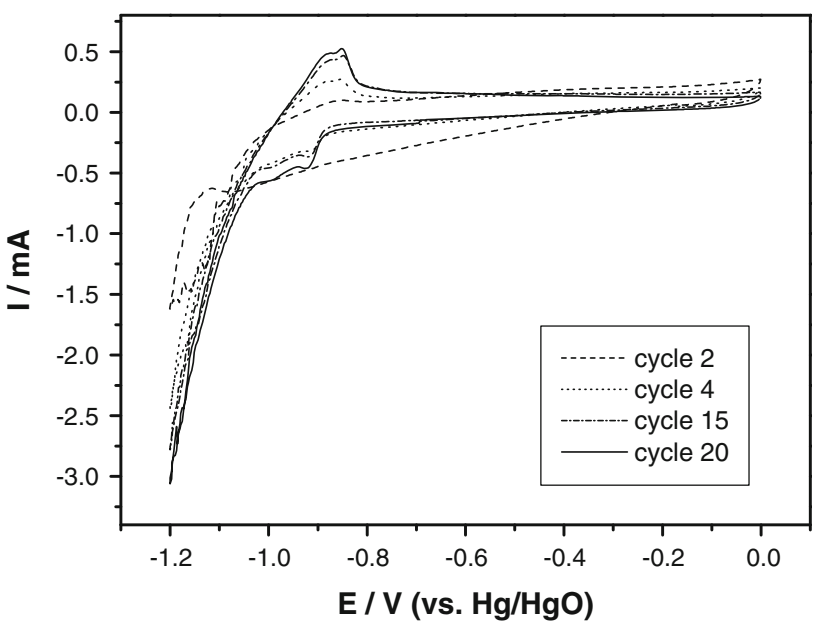

Fig. 11 Cyclic voltammograms recorded in $6 \mathrm{M} \mathrm{KOH}$ for composite $\mathrm{C}-\mathrm{Ni}-\mathrm{Pd} / \mathrm{T}$. Potential range from -1.2 to $0.0 \mathrm{~V}$. Scan rate $1 \mathrm{mV} / \mathrm{s}$

the presence $\mathrm{Ni}$ and $\mathrm{Pd}$ dopants in the carbon matrix is diminishing the average pore diameter. As a consequence of these changes, the cathodic and anodic charge decreased as compared to CG.

A small cathodic peak placed at about $-0.9 \mathrm{~V}$ and a cathodic wave commencing at about $-1.1 \mathrm{~V}$ followed by the increase in current on scanning to more negative potentials can be attributed to the reactions of hydrogen adsorption/absorption as well as the reduction of hydrated nickel oxide to metallic form. After the reversal of polarization the oxidation peak related to the oxidation of sorbed hydrogen and oxidation of nickel is recorded at about -0.8 V. As seen from Fig. 10, both peaks become more and more shaped upon cyclization.

Thermal treatment of $\mathrm{C}-\mathrm{Ni}-\mathrm{Pd}$ in air $(\mathrm{C}-\mathrm{Ni}-\mathrm{Pd} / \mathrm{T})$ resulted in the beneficial changes in the kinetics and mechanism of the reaction occurring in the regarded potential range (Fig. 11). From the comparison of curves shown in Figs. 10 and 11 one can notice that the peaks recorded for thermally activated composite $\mathrm{C}-\mathrm{Ni}-\mathrm{Pd} / \mathrm{T}$ are sharper and exhibit around a fourfold higher current. These effects can be related to the disclosure of Ni-Pd particles due to the mild oxidation of the carbon surface followed by their exposure to electrolyte. Because the heat treatment in air at $450{ }^{\circ} \mathrm{C}$ caused no changes in morphology of the composite but contributed to the modification of chemical composition of the sample surface (Table 1), one can reasonably assume that both the formation of oxygen functional group on the carbon surface and $\mathrm{Ni}-\mathrm{Pd}$ oxide on the metal surface (Fig. 8b) are responsible for these effects. The changes observed on the CV curves can be explained by about $12 \%$ increase of the BET surface area for the thermal treated sample (Table 2), a larger average pore diameter and the fact that these pores facilitate the access of the electrolyte to the nickel and palladium particles. 
No less interesting feature suggesting the changes in the reaction mechanism is the peak splitting. Such a behavior might be discussed in terms of transformation from $\alpha-(\mathrm{Pd}-\mathrm{Ni}) / \mathrm{H}$ phase to $\beta-(\mathrm{Pd}-\mathrm{Ni}) / \mathrm{H}$ phase within in the carbon matrix [41] accompanied by the $\mathrm{Ni} \leftrightarrow \mathrm{Ni}(\mathrm{OH})_{2}$ reaction [42].

Indistinctly shaped cathodic and anodic peaks on $\mathrm{CV}$ curves for metal doped electrodes in the first scanning cycles ( $\mathrm{CV}$ curves not shown here) can be attributed to the encapsulation of nickel and palladium in the carbon matrix. Electrochemical cycling carried out in the potential range from -1.2 to $0.0 \mathrm{~V}$ gave rise to the successive opening of pores in composites $\mathrm{C}-\mathrm{Ni}-\mathrm{Pd}$. As a result of such a treatment the transport of electrolyte was improved allowing contact of ions with particles of nickel and palladium, present in carbon matrix. By analogy with the synergistic interaction between nickel and platinum in the bimetallic $\mathrm{Ni}-\mathrm{Pt}$ catalysts $[43,44]$ one can assume that also in composites $\mathrm{C}-\mathrm{Ni}-\mathrm{Pd}$, nickel has a positive impact on the catalytic activity of palladium particles dispersed in the carbon matrix.

\section{Conclusions}

Incorporation of nickel and palladium dopants to the carbon matrix resulted in the changes both in morphology and in crystalline structure. The SEM and XRD data showed that $\mathrm{C}-\mathrm{Ni}-\mathrm{Pd}$ prepared by carbonization of organic gels containing nickel and palladium acetate are composed of sphere-like granules incrusted with well-crystalline nickel and palladium particles while the original CG exhibit briquette-like particles of sharp edges.

As evidenced by the CV measurements the presence of $\mathrm{Ni}-\mathrm{Pd}$ dopants in the carbon matrix contributed to a strong change in the mechanism of electrochemical reaction. The $\mathrm{C}-\mathrm{Ni}-\mathrm{Pd}$ electrode demonstrated good faradaic red-ox behavior in the potential range of the hydrogen sorption/ desorption reaction while the CG electrode exhibited $\mathrm{CV}$ curves characteristic of electrochemical double-layer capacitors with carbon electrode.

The thermal treatment of $\mathrm{C}-\mathrm{Ni}-\mathrm{Pd}$ in air at $450{ }^{\circ} \mathrm{C}$ facilitated the access of the electrolyte to the nickel and palladium particles. During this process a structural modification of the material took place and, in consequence, led to the positive changes in electrochemical properties of the composite. For thermally activated composite $\mathrm{C}-\mathrm{Ni}-\mathrm{Pd} / \mathrm{T}$ a distinct increase in current peaks arising from the reaction of hydrogen sorption/desorption was attained.

Acknowledgments The financial support from the Grant No. $31-239 / 2012$ DS-PB is gratefully acknowledged.
Open Access This article is distributed under the terms of the Creative Commons Attribution License which permits any use, distribution, and reproduction in any medium, provided the original author(s) and the source are credited.

\section{References}

1. Xu WC, Takahashi K, Matsuo Y, Hattori Y, Kumagai M, Ishiyma S, Kaneko K, Iijima S (2007) Int J Hydrogen Energy 32:2504-2512

2. Zubizarreta L, Gomez EI, Arenillas A, Ania CO, Parra JB, Pis JJ (2008) Adsorption 14:557-566

3. Zubizarreta L, Arenillas A, Pis JJ (2009) Int J Hydrogen Energy 34:4575-4581

4. Zieliński M, Wojcieszak R, Monteverdi S, Mercy M, Bettahar MM (2005) Catal Commun 6:777-783

5. Zieliński M, Wojcieszak R, Monteverdi S, Mercy M, Bettahar MM (2007) Int J Hydrogen Energy 32:1024-1032

6. Lupu D, Biriş AR, Mişam I, Jianu A, Holzhüter G, Burkel E (2004) Int J Hydrogen Energy 29:97-102

7. Zubizarreta L, Menédez JA, Job N, Marco-Lozar JP, Pirard J-P, Pis JJ, Linares-Solano A, Cazorla-Amorós D, Arenillas A (2010) Carbon 48:2722-2733

8. Pekala RW (1989) J Mater Sci 24:3221-3227

9. Lin C, Ritter JA (1997) Carbon 9:1271-1278

10. Job N, Pirard R, Marien J, Pirard J-P (2004) Carbon 42:619-628

11. Zubizarreta L, Arenillas A, Domínguez A, Menédez JA, Pis JJ (2008) J Non-Cryst Solids 354:817-825

12. Scherdel C, Gayer R, Slawik T, Reichenauer G, Scherb T (2010) J Porous Mater 15:565-569

13. Mirzaeian M, Hall PJ (2009) J Mater Sci 44:2705-2713

14. Léonard A, Blacher S, Crine M, Jomaa W (2008) J Non-Cryst Solids 354:831-838

15. Lee YJ, Jung JC, Park S, Seo JG, Baeck S-H, Yoon JR, Yi J, Song IK (2010) Curr Appl Phys 10:947-951

16. Lee YJ, Jung JC, Park S, Seo JG, Baeck S-H, Yoon JR, Yi J, Song IK (2011) Curr Appl Phys 11:1-5

17. Yoshizawa N, Hatori H, Soneda Y, Hanzawa Y, Kaneko K, Dresselhaus MS (2003) J Non-Cryst Solids 330:99-105

18. Job N, Maillard F, Marie J, Berthon-Fabry S, Pirard J-P, Chatenet M (2009) J Mater Sci 44:6591-6600

19. Skowroński JM, Osińska M (2012) Curr Appl Phys 12:911-918

20. Job N, Marie J, Lambert S, Berthon-Fabry S, Achard P (2008) Energy Convers Manag 49:2461-2470

21. Moreno-Castilla C, Maldonado-Hódar FJ (2005) Carbon 43:455-465

22. Sánchez-Polo M, Rivera-Utrilla J, von Gunten U (2006) Water Res 40:3375-3384

23. Moreno-Castilla C, Maldonado-Hódar FJ, Rivera-Utrilla J, Rodríguez-Castellón E (1999) Appl Catal A 183:345-356

24. Maldonado-Hódar FJ, Moreno-Castilla C, Rivera-Utrilla J, Hanzawa Y, Yamada Y (2000) Langmuir 16:4367-4373

25. Baumann TF, Fox GA, Sachter JH, Yosizawa N, Fu R, Dresselhaus MS (2002) Langmuir 18:7073-7076

26. Cotet LC, Baia M, Popescu IC, Cosoveanu V, Indrea E, Popp J, Danciu V (2007) J Alloys Compd 434-435:854-857

27. Lee YJ, Park S, Seo JG, Yoon JR, Yi J, Song IK (2011) Curr Appl Phys 11:631-635

28. Bekyarova E, Kaneko K (1999) Langmuir 15:7119-7121

29. Job N, Pirard R, Vertruyen B, Colomer J-F, Marien J, Pirard J-P (2007) J Non-Cryst Solids 353:2333-2345

30. Cotet LC, Gich M, Roig A, Popescu IC, Cosoveanu V, Molins E, Danciu V (2006) J Non-Cryst Solids 352:2772-2777

31. Skowroński JM, Osińska M (2009) Przem Chem 88(4):385-388 
32. Skowroński JM, Osińska M (2012) Przem Chem 91(7): 1407-1411

33. Maldonado-Hódar J, Ferro-García MA, Rivera-Utrilla J, MorenoCastilla C (1999) Carbon 37:1199-1205

34. Steiner SA III, Baumann TF, Kong J, Satcher JH Jr, Dresselhaus MS (2007) Langmuir 23:5161-5166

35. Zhang S, Fu R, Wu D, Xu W, Ye Q, Chen Z (2004) Carbon 42:3209-3216

36. Fu R, Baumann TF, Cronin S, Dresselhaus G, Dresselhaus MS, Satcher JH Jr (2005) Langmuir 21:2647-2651

37. Moreno-Castilla C, Maldonado-Hódar FJ, Pérez-Cadenas AF (2003) Langmuir 19:5650-5655
38. Dodson JJ, Neal LM, Hagelin-Weaver HE (2011) J Mol Catal A 341:42-50

39. Colussi S, Trovarelli A, Vesselli E, Baraldi A, Comelli G, Groppi G, Lorca J (2010) Appl Catal A 390:1-10

40. Zhang LL, Zhao XS (2009) Chem Soc Rev 38:2520-2531

41. Skowroński JM, Czerwiński A, Rozmanowski T, Rogulski Z, Krawczyk P (2007) Electrochim Acta 52:5677-5684

42. Skowroński JM, Ważny A (2006) J New Mater Electrochem Syst 9:345-351

43. Skowroński JM, Ważny A (2005) J Solid State Electrochem 9:890-899

44. Skowroński JM, Ważny A (2006) Mater Sci-Pol 24:91-97 